Historia Slavorum Occidentis

2021, nr $3(30)$

ISSN 2084-1213

DOI: $10.15804 /$ hso2 10312

Rafae Stobiecki (ŁóDź)

ORCID: 0000-0002-1458-1657

\title{
Marksizm na tle innych nurtów w polskiej historiografii powojennej
}

[...] dla ciebie i dla twoich humanistów największym osiągnięciem marksizmu jest metodologia nauk, a tymczasem jego największym osiągnięciem jest stworzenie Związku Radzieckiego. Marksizm jest cenny nie dlatego, że potrafi rozszyfrować ideologię społeczną Balzaka, ale dlatego, że potrafił w porę zdemaskować ideologię Trockiego... ${ }^{1}$

Słowa kluczowe: marksizm, polska historiografia po 1945 r., teoria historii Keywords: marxism, Polish historiography after 1945, theory of history

Abstract: This paper aims to present the methodological face of Polish historiography after World War II. In the centre of the Author's interest is Marxism and its role in historians' research practice. The article briefly mentions other methodological trends present in Polish historiography after 1956 (Annales school, individualistic historicism).

I. Przywołany powyżej cytat dobrze, jak sądzę, ilustruje podwójny status marksizmu w krajach Europy Środkowo-Wschodniej, zarówno jako teorii historii, jak i ideologii. Władza w zależności od swoich potrzeb gotowa była traktować marksizm, czy precyzyjniej marksizm-leninizm, w sposób mniej lub bardziej instrumentalny. W ni-

1 A. Kijowski, Dziesięć lat życia, [w: ] Rachunek pamięci, wstęp M. Głowiński, Warszawa 2012, s. 142-143. Jest to zbiór rozliczeniowych z epoką stalinizmu wypowiedzi pisarzy i publicystów zatrzymany przez cenzurę w $1957 \mathrm{r}$. 
niejszym tekście chciałbym skoncentrować się jednak przede wszystkim na metodologicznym wymiarze teorii marksistowskiej i pokazać jej rolę w praktyce badawczej polskich historyków po 1945 r. $^{2}$ Przez czterdzieści z górą lat marksizm stanowił dominujący i uprzywilejowany przez władzę sposób myślenia o przeszłości. Uproszczeniem byłoby jednak sprowadzanie całości dziejów historiografii w okresie PRL jedynie do rozważań, jakie konsekwencje przyniosło jej narzucenie marksistowskich czy marksistowsko-leninowskich wzorów. Tym bardziej że w przeciwieństwie do ZSRR i większości krajów poddanych radzieckiej dominacji w Polsce historiografia odwołująca się do marksizmu, poza krótkim okresem tzw. klasycznego stalinizmu (przełom lat czterdziestych i pięćdziesiątych, aż do 1956 r.) nie uzyskała statusu „jedynego dziejopisarstwa”. Po październikowej odwilży marksizm stał się bowiem, co prawda w dalszym ciągu usilnie popieraną przez władze, ale „zaledwie” jedną z kilku teoretycznych inspiracji obecnych w polskim dziejopisarstwie ${ }^{3}$.

2 W szeroko rozumianej literaturze poświęconej powojennym dziejom polskiej historiografii, zagadnienie to nie zostało jak dotychczas wszechstronnie opracowane. Spośród niewielu prac na ten temat należy wymienić: A. Malewski, J. Topolski, Metoda materializmu historycznego w pracach historyków polskich, Studia Filozoficzne 6 (1959), s. 129-154; W. Markiewicz, Miejsce i rola marksizmu w badaniach społecznych, Nauka Polska 1 (1984), s. 43-54; J. Topolski, Polish Historiography and Marxism After World War II, [w:] Asian and European History in Transitional Period: Collection of Essays in the Celebration of Dr. Tae-Young Lee's Sixtieth Birthday, Seoul 1992, s. 403-414; tenże, Polish Historiography and Marxism After World War II, Studies in Soviet Thought 43 (1991), No. 2: Polish Philosophy at the Crossroads, s. 169-183; A. Zybertowicz, Między dogmatem a programem badawczym. Problemy stosowania materializmu historycznego we wspótczesnej historiografii polskiej, Warszawa 1990; R. Stobiecki, Między dogmatem ideologicznym a modernizacja. Marksizm a historiografia $w$ Polsce po drugiej wojnie światowej, [w:] tegoż, Historiografia PRL. Ani dobra, ani mądra, ani piękna... ale skomplikowana, Warszawa 2007, s. 163-183; M. Górny, Przede wszystkim ma być naród... Marksistowskie historiografie w Europie Środkowo-Wschodniej, Warszawa 2007. Na marginesie innych problemów o relacji między marksizmem a historiografią polską pisali także: A. Radomski, Kultura - tekst - historiografia, Lublin 1999, s. 153-224; G. Labuda, Rozwój metod dziejopisarskich od starożytności do wspótczesności. Część I: do schyłku XIX wieku, Poznań 2003, s. 155-188 (autor omówił m.in. rolę marksizmu w pracach H. Łowmiańskiego i J. Topolskiego); A. Sosnowska, Zrozumieć zacofanie. Spory historyków o Europę Wschodnia (1947-1994), Warszawa 2004; J. Connelly, Zniewolony uniwersytet: sowietyzacja szkolnictwa wyższego w Niemczech Wschodnich, Czechach i Polsce, przeł. W. Rodkiewicz, Warszawa 2014; J. Pomorski, Homo metahistoricus. Studium sześciu kultur poznajacych historię, Lublin 2019; P. Gałkowski, Poznawanie dziejów czy wytwarzanie historii? Jerzego Topolskiego przemiany poglądów na uprawianie historii, Poznań 2019; R. Stobiecki, Historiografia PRL. Zamiast podręcznika, Łódź 2020.

3 Nieporozumieniem jest zatem pełne utożsamianie historiografii okresu PRL-u z marksizmem 
Celem niniejszego eseju jest zarysowanie metodologicznego krajobrazu, jaki towarzyszył uprawianiu historii w Polsce po drugiej wojnie światowej. Poza sferą moich zainteresowań pozostawiam zatem, bliską mi skądinąd, historiografię emigracyjną. Wbrew głoszonym niekiedy opiniom PRL nie był statycznym, totalitarnym fenomenem, który trwał niezmiennie od 1945 r. aż do końca lat osiemdziesiątych. Na przestrzeni lat zmieniała się rzeczywistość społeczno-polityczna, co nie pozostawało bez wpływu na przemiany zarówno w historiografii, jak i w środowisku badaczy. W dziejach powojennej polskiej nauki historycznej można, jak sądzę zasadnie, wyróżnić następujące etapy: 1. 1945 r. - do przełomu lat czterdziestych i pięćdziesiątych; 2. przełom lat czterdziestych i pięćdziesiątych do 1956 r.; 3. lata 1956-19894. Według tego klucza chronologicznego chciałbym uporządkować moje dalsze uwagi.

II. W pierwszym okresie mieliśmy do czynienia z pluralizmem postaw teoretyczno-metodologicznych i zarysowującą się ofensywą marksizmu. Świadomość potrzeby zmian była udziałem zdecydowanej większości środowiska, o czym świadczy choćby drukowane w pierwszym powojennym numerze „Kwartalnika Historycznego” Słowo od Redakcji podpisane przez Romana Grodeckiego i Kazimierza Lepszego ${ }^{5}$. $\mathrm{W}$ podobnym duchu wypowiadali się inni, m.in. Henryk Barycz w pisanym pod wrażeniem klęski powstania warszawskiego artykule $O$ nowe drogi polskiej historiografi ${ }^{6}$. Krytykowano międzywojenny model uprawiania historiografii oparty na doktrynie indywidualistycznego historyzmu, dominacji historii politycznej, kulcie faktu, naiwnym często psychologizmie, odwołujący się do roli wybitnych jednostek w dziejach ${ }^{7}$. Na tym tle propozycja marksistowska wydawała się atrakcyjna i bynajmniej nie była kojarzona jedynie z ideologią. Na czym polegała jej atrakcyjność? Wydaje się, że przede wszystkim marksizm oferował całkowicie odmienny od dotychczasowych system wyobrażeń o świecie, a więc także o historii. System

i używanie wobec niej terminu „historiografia marksistowska”. Por. Marksizm i istoriczeskaja nauka w stranach centralnoj i jugowostocznoj Jewropy (1870-1965), red. W.A. Djakow, Moskwa 1993, szczególnie s. 109-155.

4 To oczywiście tylko jedna z propozycji dotyczących chronologii zjawiska. Z pewnością istotną rolę odegrała także cezura 1980/1981. Inną periodyzację, bardziej zniuansowaną wprowadziłem w książce Historiografia PRL. Zamiast podręcznika.

5 R. Grodecki, K. Lepszy, Stowo od Redakcji, Kwart. Hist. 53 (1946), nr 1, s. 395.

6 H. Barycz, O nowe drogi polskiej historiografii, Nauka i Sztuka 2 (1946), s. 324-336.

7 Szerzej na ten temat zob. R. Stobiecki, Historia pod nadzorem. Spory o nowy model historii $w$ Polsce (II połowa lat czterdziestych - początek lat pięćdziesiątych), Łódź 1993, s. 48-93. 
całościowy, wszechogarniający, eliminujący chaos, wprowadzający na jego miejsce ład i porządek. Zaspokajał w ten sposób, szczególnie widoczną po doświadczeniach drugiej wojny światowej, elementarną potrzebę racjonalizacji dziejów, nadania im dalszego sensu. Oddziaływał zatem jako historiozofia czy też wręcz jako „świecka religia”. Przygotowało to grunt pod zauważalną już wówczas, chociażby w podręczniku Adama Schaffa (Wstęp do teorii marksizmu. Zarys materializmu dialektycznego i historycznego, I wyd. Warszawa 1947), tendencję zmierzającą do uczynienia zeń oficjalnej metanauki.

Wspomniane historiozoficzne oddziaływanie materializmu historycznego miało jednak także pozytywne aspekty. Marksizm inspirował zwrot w stronę teorii, podkreślał jej rolę w badaniach historycznych. Znalazło to swoje odzwierciedlenie w ówczesnych dyskusjach metodologicznych, toczonych nie tylko w Polsce ${ }^{8}$.

Jednocześnie, pośrednio lub bezpośrednio, marksizm „odkrywał” przed polskimi historykami nowe, dotychczas zaniedbywane obszary zainteresowań. Dotyczyło to mającej w Polsce wielkie tradycje (Franciszek Bujak, Jan Rutkowski) - lecz pozostającej na marginesie życia naukowego - historii gospodarczej, historii społecznej rozumianej jako dzieje mas ludowych (historia społeczna zamiast historii elit), interpretowanej w optyce klasowej historii ustroju (Stanisław Śreniowski). O roli marksizmu w pierwszych latach powojennych tak pisał po pewnym czasie, $\mathrm{z}$ innej już zupełnie perspektywy (po przełomie październikowym) Witold Kula: „Marksizm ukazywał nam nowe problemy i nowe metody. Sprawy, które dawniej wydawały się proste, ukazywały się w całej ich komplikacji - i odwrotnie. Problemy rzekomo rozwiązane zamieniały się w wielkie znaki zapytania. Marksizm nęcił perspektywami i możliwościami naukowymi ludzi nieraz dalekich ideologicznie. Twórczy był to ferment”"

Już wówczas były widoczne zagrożenia, które dały o sobie znać w latach następnych. Wyraźnie dostrzegano je na emigracji. Marian Kukiel, komentując przebieg VII Powszechnego Zjazdu Historyków Polskich we Wrocławiu w 1948 r. zauważał:

Nie sam materializm historyczny stanowi też właściwe niebezpieczeństwo. W atmosferze wolności tezy historyków marksistów mogłyby dać pole do dyskusji płodnych, dać bodźce do nowych badań, przyczynić się do postępu nauki. Nie-

8 R. Stobiecki, Historia pod nadzorem, s. 11-34; G. Iggers, Historiography in the Twentieth Century: From Scientific Objectivity to the Postmodern Challenge, Hanover-London 1997; M. Górny, Przede wszystkim ma być naród.

9 W. Kula, Rozważania o historii, Warszawa 1958, s. 11. 
bezpieczeństwo jest w tym, że tzw. materializm historyczny czy dialektyczny występuje tu jako narzędzie „dyktatury proletariatu”, a raczej totalistycznego policyjnego państwa, że historycy marksiści nie na to są, by dociekać prawdy, ale na to, by na kopyto rządowe przerabiać historię ${ }^{10}$.

III. Przełom lat czterdziestych i pięćdziesiątych zapoczątkował proces stalinizacji polskiej historiografii. Jego częścią była zakrojona na szeroką skalę, prowadzona często metodami administracyjnymi ofensywa marksizmu. Marksizm w wydaniu leninowsko-stalinowskim miał podwójne oblicze. Aspirował do roli oficjalnej metanauki oraz ideologicznego narzędzia mającego legitymizować totalitarny porządek społeczno-polityczny, tworzony przez partię-państwo. Jak zauważył w 1992 r. rosyjski badacz Andriej Miercałow

[...] nauka historyczna zajmowała w ideologicznym instrumentarium stalinizmu szczególne miejsce [...]. Reżim mógł istnieć jedynie w warunkach ustawicznego stanu wyjątkowego. Ukierunkowywał on w sposób ogólny pogląd na przeszłość, główną zaś destrukcyjną robotę wykonywali sami historycy. Nie byli oni bynajmniej biernym przedmiotem stalinowskich lub breżniewowskich manipula$\mathrm{cji}^{11}$.

Postępująca w okresie stalinizmu dogmatyzacja i ideologizacja marksizmu prowadziła do tego, że w obrębie historiografii powoli zatracał on swoje funkcje modernizacyjne. Co za tym idzie, przestawał być dla historyków twórczą inspiracją, zmieniającą ich zapatrywania na dzieje, a stawał się bezkrytycznym wyznaniem wiary. Ponadto, co bardzo istotne, w owych latach deklaratywna choćby akceptacja marksizmu stała się warunkiem sine qua non jakiejkolwiek działalności naukowej. Nie miejsce tu na szczegółową analizę konsekwencji aplikacji na polskim gruncie stalinowskiego modelu nauki historycznej. Spuentuję ten fragment jedynie cytatem, który w sposób metaforyczny ilustruje cele, jakie postawiła sobie władza. Wybitny rosyjski fizyk Piotr Kapica pisał w 1989 r.:

W naszej filozofii wydarzyło się to, co wydarzyłoby się z szachistami, gdyby każdego gracza przegrywającego w grze, pozbawiać prawa gry w szachy. Jest rzeczą oczywistą, że pozostanie tylko jeden zawodnik, co prawda najsilniejszy, ale nie

10 M. Kukiel, Nauki historyczne pod komunistycznym ciśnieniem, Przegląd Polski 2 (1949), s. 15.

11 A. Miercałow, Istorija i stalinizm, Moskwa 1991, s. 411. Podaję w tłumaczeniu A.F. Grabskiego, Stalinowski model historiografii, Dzieje Najnowsze 24 (1992), nr 3, s. 23. 
będzie miał on już z kim grać i gra przestanie istnieć. W Związku Radzieckim pozostali tylko filozofowie-materialiści i wyćwiczyli się (razuczilis) oni we wzajemnych dyskusjach i walkach. To nieuchronnie stałoby się z każdym uczonym, nawet najwybitniejszym, gdyby nie mógł on z nikim walczyć w obronie swoich poglądów ${ }^{12}$.

Choć opinia ta dotyczy jedynie filozofii, ma, jak sądzę, wymiar uniwersalny.

Do 1956 r., mimo wielu zabiegów władz, nie udało się narzucić historiografii polskiej jednolitego oblicza metodologicznego. Uważana powszechnie za symbol stalinizacji polskiego dziejopisarstwa słynna konferencja w Otwocku, zorganizowana z wielkim rozmachem na przełomie 1951 i 1952 r., zakończyła się porażką najbardziej dogmatycznie nastawionej grupy historyków-marksistów (Żanna Kormanowa, Celina Bobińska, Tadeusz Daniszewski ${ }^{13}$. Nie zmienia to faktu, że pozostaje ona „czarną kartą” w dziejach polskiej historiografii, a lektura dwóch obszernych tomów materiałów budzi dziś smutek i zadumę nad losami dużej części reprezentantów środowiska.

IV. Przełom październikowy rozpoczął nowy okres w dziejach polskiej historiografii. Przyniósł on wiele istotnych zmian. Krytyka marksizmu zaowocowała odrzuceniem stalinowskiej ortodoksji oraz odrodzeniem się swego rodzaju pluralizmu metodologicznego, limitowanego jednak w dalszym ciągu przez władze. Dostrzec go można w metodologicznych postawach ówczesnych historyków, reprezentujących - jak się wydaje - przynajmniej cztery tradycje uprawiania historii.

Pierwszą - marksistowską - w której ramach należałoby z kolei wyróżnić dwa nurty: „ortodoksyjny” i „rewizjonistyczny”. Przez cały okres po 1956 r. toczyła się między owymi nurtami, mówiąc słowami Pierre’a Bourdieu, „walka o pozycję w polu", o uznanie własnej wizji materializmu historycznego za obowiązującą. Pisałem o tym w kontekście analizy postawy i dorobku Jerzego Topolskiego ${ }^{14}$. Dziś często zapominamy, że dla środowiska historyków nie było bez znaczenia, jaki marksizm ostatecznie zatriumfuje - czy będzie nim wykładnia środowiska poznań-

\footnotetext{
12 P. Kapica, Pisma o naukie, Moskwa 1989, s. 16.

13 Szerzej na ten temat: R. Stobiecki, Pierwsza Konferencja Metodologiczna Historyków Polskich, [w: ] tegoż, Historiografia PRL, s. 96-118; T.P. Rutkowski, Nauki historyczne w Polsce 1944-1970. Zagadnienia polityczne i organizacyjne, Warszawa 2007, s. 191-210; S. Kieniewicz, Pamiętniki, Kraków 2021, s. 566-572.

14 R. Stobiecki, Jerzy Topolski (1928-1998). Marksista, który miat odwagę różnić się od innych, [w:] tegoż, Historycy polscy wobec wyzwań XX wieku, Poznań 2014, s. 351-373.
} 
skiego, marksizm Adama Schaffa czy... Andrzeja Werblana. Trwaniu nurtu „ortodoksyjnego" sprzyjało to, że w latach 1956-1989 marksizm zachował bez wątpienia sporo ze swojej funkcji legitymizującej panujący porządek społeczno-polityczny. Nie zmieniła tego fala krytyki z lat 1956/1957 ${ }^{15}$. To, że pozostał on w dalszym ciągu oficjalną doktryną państwową, sprzyjało eksponowaniu w nim przede wszystkim tych treści, które miały związek z ideologią. Przywołana jako motto wypowiedź Andrzeja Kijowskiego, jest, jak sądzę, dobrą ilustracją tego zjawiska. W wielu pracach opublikowanych już po 1956 r. spotykamy ten uproszczony sposób adaptacji teorii materializmu historycznego. Polegał on na deklaratywnym opowiedzeniu się historyka po stronie socjalizmu, postępu, przeciw wyzyskowi klasowemu. Widoczne to jest choćby w tekstach Władysława Góry, Norberta Kołomejczyka i innych „klasyków" najnowszej historii Polski ${ }^{16}$.

Inną przyczyną powodującą utrwalanie się wspomnianej legitymizującej funkcji marksizmu była dominacja zarówno w podręcznikowych opracowaniach, jak i w praktyce dziejopisarskiej, „wulgarnej” (określenie brytyjskiego historyka-marksisty Erica Hobsbawma) wersji teorii materializmu historycznego. Krytyka stalinowskich deformacji okazała się w praktyce dość powierzchowna. Obiegowa wykładnia marksizmu, a co za tym idzie - sposób jego aplikacji w obrębie historiografii - opierały się na ekonomicznej interpretacji dziejów, niosącej ze sobą przekonanie, że czynnik gospodarczy jest czynnikiem podstawowym, od którego wszystkie inne są zależne. W praktyce dziejopisarskiej prowadziło to do tego, że historyk dziejów politycznych uważał za niezbędne poprzedzenie swoich zasadniczych rozważań wstępem zawierającym, często zupełnie przypadkowo dobrane, informacje dotyczące zmian w życiu ekonomicznym. Jeszcze innym przykładem spuścizny marksizmu czasów stalinowskich była wszechwładna dominacja w historiografii polskiej teorii formacji społeczno-ekonomicznych. W wielu syntezach i monografiach publikowanych po 1956 r. pełniła ona w dalszym ciągu funkcję osi syntezy, wokół której organizowany był cały materiał faktograficzny, np. Dzieje Polski pod redakcją Jerzego Topolskiego $(1976)^{17}$, Zarys historii Polski pod redakcją Janusza Tazbira $(1979)^{18}$ czy

\footnotetext{
15 Szerzej na ten temat zob. A. Czyżewski, Proces destalinizacji polskiej nauki historycznej $w$ drugiej połowie lat 50. XX wieku, Warszawa 2007.

16 Szerzej na ten temat zob. R. Stobiecki, Najnowsze dzieje Polski w syntezach historycznych okresu PRL, Przegląd Zachodni 4 (1994), s. 111-122.

17 Dzieje Polski, red. J. Topolski, Warszawa 1976 (wyd. 1).

18 Zarys historii Polski, red. J. Tazbir, Warszawa 1979 (wyd. 1).
} 
też czterotomowa tzw. synteza krakowska autorstwa Jerzego Wyrozumskiego, Józefa Andrzeja Gierowskiego i Józefa Buszki (1978-1979) ${ }^{19}$.

Jednocześnie po 1956 r. w marksizmie wyraźnie zaznaczyły się tendencje „rewizjonistyczne" (moje uwagi ograniczam do wąsko rozumianej historiografii, pomijając tzw. warszawską szkołę historyków idei) ${ }^{20}$. Chodziło o uczynienie zeń na wzór pierwszych lat powojennych, teorii żywej, stymulującej dalszy rozwój historiogra$\mathrm{fii}^{21}$. Postawę tę dobrze charakteryzuje następująca, wyrażona ex post, bo już w latach dziewięćdziesiątych, wypowiedź Bronisława Geremka:

[...] dla mnie marksizm stanowił sposób myślenia, sposób rozumienia i wciąż uważam go za przydatny, nawet teraz, gdy rozpatruję problemy społeczeństwa współczesnego, które obserwuję i w którym żyję. Bardzo często mam poczucie, że historia nie uczy mnie niczego oprócz sposobu pojmowania. Tylko taką naukę

19 J. Wyrozumski, Historia Polski do roku 1505, Warszawa 1978 (wyd. 1); J.A. Gierowski, Historia Polski 1505-1764, Warszawa 1978 (wyd. 1); tenże, Historia Polski 1764-1864, Warszawa 1979 (wyd. 1); J. Buszko, Historia Polski 1864-1948, Warszawa 1979 (wyd. 1).

20 Tym samym na marginesie pozostawiam problem tzw. rewizjonizmu w polskim marksizmie po 1956 r. - który symbolizują m.in. nazwiska L. Kołakowskiego i K. Pomiana - i jego wplywu na przemiany polskiej humanistyki, $\mathrm{w}$ tym także historii. Zagadnienie to wymagałoby zupełnie oddzielnego potraktowania. Ograniczę się tylko do zacytowania wielce znamiennego fragmentu przedmowy K. Pomiana do wydanej w 1961 r. przez wydawnictwo Książka i Wiedza pracy francuskiego marksisty Luciena Goldmanna, Nauki humanistyczne a filozofia, przeł. E. Jerzewska, Warszawa 1961. Komentując koncepcję zachodnioeuropejskiego marksisty, jeden z twórców warszawskiej szkoły historyków idei pisał m.in.: „Tak pojmowana koncepcja Marksa implikuje pogląd, że nie istnieje autonomiczna historia gospodarki, myśli, religii, a nadto, że jeśli ujmuje się proces dziejowy w jego całokształcie, to nie można uznać żadnej poszczególnej sfery życia spolecznego za wyznaczającą ten proces w sposób konieczny. Wynikałoby stąd z kolei, że twierdzenie o prymacie czynników ekonomicznych oznacza u Marksa tyle tylko, iż w historii minionej ludzie musieli poświęcać większą część swej działalności na rozwiązywanie problemów dotyczących wytwarzania i dystrybucji dóbr materialnych, co prowadziło do kształtowania się prymatu gospodarki jako dynamicznego czynnika postępu historycznego", tamże, s. 9. Zob. także L. Kołakowski, Pochwata niekonsekwencji. Pisma rozproszone z lat 1955-1968, oprac. Z. Mentzel, t. 1-3, Londyn 1989. Szerzej na ten temat: R. Sitek, Warszawska szkoła historyków idei. Między historiq̨ a teraźniejszością, Warszawa 2000. O samym fenomenie rewizjonizmu z perspektywy politologicznej pisała M. Mikołajczyk, Rewizjoniści. Obecność w dyskursach okresu PRL, Kraków 2014.

21 Przykładem powolnego narastania dążeń zmierzających do rewizji ortodoksyjnej interpretacji materializmu historycznego mogą być pisane głównie w latach 1951-1953 Gusta Witolda Kuli, włączone do wydanych w 1958 r. Rozważań o historii. 
można wyciągnąć - sposób rozumienia. W tym sensie marksizm nie stracił na ważności ${ }^{22}$.

Na inny aspekt tego samego problemu zwrócił uwagę Jerzy Jedlicki. W wywiadzie z 2005 r., wymownie zatytułowanym Nie marksizm mnie uwiódt historyk ten stwierdził m.in.: „Brałem z marksizmu jego wyczulenie na konflikt klasowy, na położenie robotników, na rozwarstwienie wsi, analizę kryzysów gospodarczych, ale nie przypominam sobie, żebym pasjonował się jego stroną filozoficzną, także filozofią dziejów”23. W tym kontekście warto przywołać również słowa Krzysztofa Pomiana, który tak w 2018 r. bilansuje swoje „relacje z marksizmem”:

Jestem nadal przekonany o istnieniu determinacji społecznych i podziałów społecznych, jestem przekonany, że społeczeństwo jest trawione wewnętrznymi konfliktami [...]. Nie są to zresztą poglądy swoiście marksistowskie, ale Marks wysłowił je szczególnie mocno. Zarazem jestem pewien - dochodziłem do tego powoli - że żadne „stosunki produkcji”, żadne „siły wytwórcze” nie są w stanie wytłumaczyć określonego dzieła filozoficznego, literackiego czy artystycznego ${ }^{24}$.

Ryzykując pewne uproszczenie, można stwierdzić, że dążenia do swoistej „odnowy” marksizmu zaznaczyły się na dwóch nie do końca zbieżnych ze sobą polach - metodologicznym, a więc w rozważaniach skoncentrowanych na próbie reinterpretacji niejako „czystej” teorii, oraz na polu bliższym praktyce dziejopisarskiej, na którym próbowano weryfikować przydatność teorii materializmu historycznego w badaniach dotyczących np. epoki feudalizmu, czy zagadnienia roli rewolucji w dziejach. Ta pierwsza związana była najsilniej ze środowiskiem poznańskim. Wydaje się, że pierwszą wyraźną artykulacją poglądów tej grupy był opublikowany w 1958 r. artykuł autorstwa Antoniego Malewskiego i Jerzego Topolskiego zatytulowany Metoda materializmu historycznego w pracach historyków polskich ${ }^{25}$. W tekście tym obaj autorzy nie tylko poddali krytyce dotychczasowy sposób adaptacji marksizmu w historiografii, lecz także zaproponowali w ogólnych zarysach nową, szczególnie na polskim gruncie, interpretację tej teorii. W latach następnych była ona rozwijana przede wszystkim przez Topolskiego w takich jego pracach jak: Meto-

22 G. Duby, B. Geremek, Passions communes: entretiens avec Philippe Sainteny, Paris 1992; cyt za wyd. polskim: Wspólne pasje, przeł. z jęz. franc. E.T. Sadowska, Warszawa 1995, s. 24.

23 J.Jedlicki, Nie marksizm mnie uwiódt, [w:] M. Bajer, Blizny po ukąszeniu, Warszawa 2005, s. 81.

K. Pomian, Wśród mistrzów i przyjaciót, Gdańsk 2018, s. 23.

25

Zob. przyp. nr 2. 
dologia historii (wyd. 1 - 1968) czy późniejszych Marksizm i historia (1977) i Teoria wiedzy historycznej (1983).

W latach sześćdziesiątych i siedemdziesiątych, obok wspomnianej próby rewizji oficjalnego marksizmu podjętej przez środowisko poznańskie, warto odnotować także inne formy obecności teorii materializmu historycznego w historiografii polskiej. Teoria ta w dalszym ciągu żywo inspirowała przynajmniej część środowiska. W tym przypadku marksizm sprzyjał bardziej integralnym ujęciom przeszłości, obejmującym wszystkie sfery dziejowej rzeczywistości, nawet jeżeli były one wyraźnie zhierarchizowane w oparciu o zasadę determinizmu ekonomicznego. Stanowił argument w rękach tych badaczy, którzy pragnęli wyjść poza wykład historii koncentrujący się na wydarzeniach politycznych, walce dyplomatycznej, dziejach konfliktów zbrojnych. Rzecz charakterystyczna, że tak rozumiana inspiracja marksizmem była dostrzegalna przede wszystkim w badaniach nad epokami dawniejszymi - średniowieczem i epoką nowożytną. Widoczna była w studiach nad historią powszechną, rozumianą także jako dzieje obszarów pozaeuropejskich, w badaniach nad klasycznymi zagadnieniami mieszczącymi się w Braudelowskiej „historii długiego trwania” (feudalizm, problem przejścia od feudalizmu do kapitalizmu), w studiach nad zagadnieniem rewolucji. Przykładowo można w tym miejscu wymienić prace Witolda Kuli, Mariana Małowista czy Jana Baszkiewicza ${ }^{26}$.

Druga tradycja uprawiania historiografii, która zaznaczyła się po 1956 r., nawiązywała do francuskiej szkoły „Annales”. Jej zwolennicy próbowali adoptować na polski grunt charakterystyczne dla tego środowiska badania z zakresu historii społeczno-gospodarczej i historii mentalności. Nieco paradoksalnie pomostem umożliwiającym nawiązanie tych polsko-francuskich więzi historiograficznych, a potem ich zintensyfikowanie, okazał się marksizm ${ }^{27}$. Istotne były pod tym względem zarówno podobna postawa wobec historii, jak i wynikające z niej wspólne zainteresowania

26 W. Kula, Teoria ekonomiczna ustroju feudalnego. Próba modelu, Warszawa 1962; M. Małowist, Wschód a Zachód Europy w XIII-XVI wieku. Konfrontacja struktur społeczno-gospodarczych, Warszawa 1973; J. Baszkiewicz, Wolność, Równość, Własność. Rewolucje burżuazyjne, Warszawa 1981. Por. S. Kwiatkowski, Polska mediewistyka w czasach maszynopisu. O wymuszonej modernizacji i okolicznościach jej przemijania, Poznań 2010; T. Siewierski, Marian Małowist i kragg jego uczniów. Z dziejów historiografii gospodarczej w Polsce, Warszawa 2016. 27 G. Duby, B. Geremek, Wspólne pasje, s. 24. Szerzej na ten temat zob. P. Pleskot, Intelektualni sąsiedzi. Kontakty historyków polskich ze środowiskiem „Annales” 1945-1989, Warszawa 2010; M. Kula, Mimo wszystko bliżej Paryża niż Moskwy. Książka o Francji, PRL i o nas, historykach, Warszawa 2010. Por. także moją recenzję obu tych prac Dwugłos o historiograficznych kontaktach polsko-francuskich, Kwart. Hist. 119 (2012), nr 3, s. 58-593. 
badawcze. Mam na myśli m.in. odrzucenie perspektywy zmierzającej do indywidualizacji faktów i procesów historycznych na rzecz badania zjawisk powtarzalnych, dających się uchwycić w długich ciągach chronologicznych. W przedmowie do opublikowanej w 1960 r. pracy Marca Blocha Pochwała historii Witold Kula pisał:

Bloch bliski jest nam [marksistom, jak wynika jednoznacznie z całego tekstu R.S.] przede wszystkim swym głębokim historyzmem. Świadomością wszechstronnej, nieustannej i nigdy nie dość przez historyka nie zgłębionej zmienności, świadomością nieskończonej różnorodności spotykanych w granicach czasu i przestrzeni środowisk ludzkich, instytucji społecznych, ludzi samych. Cechowało to zresztą całą szkołę Annales. Zewnętrznym tylko znakiem tej postawy jest preferencja, jaką z reguły daje się w tej szkole liczbie mnogiej na pojedynczą: w obawie hipostazowania nie lubiło się tam i nie lubi mówić „burżuazja” czy „feudalizm” - raczej „burżuazje” czy „feudalizmy”"

Z pewnością do tego nurtu nawiązywała późna twórczość cytowanego Kuli, a także wielu innych badaczy. Janusz Żarnowski uznał go wręcz za „pioniera historii społecznej orientującej się na «Annales»" ${ }^{29}$. Potwierdza to skądinąd tezę, że polskie badania w zakresie dziejów społecznych wywodziły się w dużym stopniu właśnie $\mathrm{z}$ marksizmu ${ }^{30}$.

Trzecią opcją metodologiczną, którą jedynie sygnalizuję, była tradycja odwołującą się do tzw. indywidualistycznego historyzmu, akcentującego przede wszystkim duchowy wymiar przeszłości, polityczną warstwę wydarzeń i rolę wybitnych jednostek. Przykładem może być w tym kontekście, bijące rekordy popularności w latach sześćdziesiątych i później, pisarstwo Pawła Jasienicy. Teoretyczno-metodologiczne założenia dzieł Jasienicy wyrastały ze sprzeciwu wobec marksistowskiej koncepcji historii. Po pierwsze, autor Polski Piastów zakwestionował narzucone przez marksizm ujęcie historii Polski w ramach teorii formacji społeczno-ekonomicznych. Jego pisarstwo historyczne to powrót do koncepcji periodyzacyjnych rodem z XIX

28 W. Kula, Przedmowa, [w: ] M. Bloch, Pochwała historii, czyli o zawodzie historyka, przeł. W. Jedlicka, Warszawa 1960, s. 16. W tym samym tekście polski historyk zakreślał jednak także wyraźne różnice metodologiczne między środowiskiem „Annales” a marksizmem. Dotyczyły one w przypadku M. Blocha przeciwstawiania się wszelkim próbom hierarchizacji elementów życia społecznego, niedostrzegania roli walki klasowej, zagadnienia osądów historycznych. Tamże, s. 17-18.

29 J. Żarnowski, Historia społeczna. Metodologia - ewolucja - perspektywy, Warszawa 2011, s. 158.

30 Por. tamże, s. $158-169$. 
stulecia, opartych o kryterium dynastyczne i przemiany w sferze ustrojowej. Po drugie, Jasienica odrzucił rozumienie historii w kategoriach kolektywnych procesów (rola mas w historii) i rządzących nią rzekomo praw, na rzecz uczynienia głównym podmiotem dziejów człowieka jako ich głównego sprawcę. Po trzecie, rehabilitował, potępianą ze względów ideologicznych, historię polityczną. Jego bohaterami są „władcy”, „konflikty zbrojne”, „ludzkie ambicje, wielkie czyny i zaniechania” [cudzysłów - R.S.]. Wreszcie po czwarte, autor Polski Jagiellonów odmiennie od marksistów rozumiał kategorię narodu. Podkreślał rolę więzi etnicznych i kulturowych łączących wspólnotę, silnie akcentował słowiańskie pochodzenie naszych przodków (teoria autochtonizmu). Do wspomnianych inspiracji indywidualistycznym historyzmem odwoływali się także badacze akademiccy. Przykładem może być nieco dziś zapomniana synteza autorstwa Władysława Czaplińskiego ${ }^{31}$.

Wreszcie ostatnią orientację, którą pragnę tu wyróżnić trochę z przekory, reprezentowali ci badacze, których postępowanie charakteryzowała niechęć do wszelkiego teoretyzowania, co po doświadczeniach stalinizmu, nie bez racji, kojarzyło się przede wszystkim nie z metodologią, ale z ideologią. Jest ona skądinąd widoczna $\mathrm{w}$ środowisku do dziś. Uprawiali oni tzw. żywiołowy pozytywizm, polegający na kulcie faktu, poprzestający na samym, często bardzo szczegółowym, opisie zjawisk bez ich głębszego wyjaśnienia, przekonani, że możliwe jest pełne odwzorowanie minionej rzeczywistości na podstawie klasycznej definicji prawdy. Owo dotarcie do „prawdy" miały/mają gwarantować wspomnianym historykom obfite cytaty ze źródeł, co niekiedy czyniło/czyni ich narrację o przeszłości wyjątkowo nudną i jednostronną.

V. Pora na konkluzje. Zaprezentowana wyżej metodologiczna panorama postaw polskich historyków w okresie powojennym daleka jest z pewnością od kompletności. Można sobie bez trudu wyobrazić także inną typologię, inne rozłożenie akcentów, wreszcie inne przykłady.

Cechą charakterystyczną historiografii doby PRL była z pewnością dominacja marksizmu czy - w pewnym okresie - marksizmu-leninizmu w różnych jego wer-

31 Mam na myśli książkę Zarys dziejów Polski do roku 1864, Kraków 1985. O twórczości P. Jasienicy pisali: A. Mękarski, Między mitem a polityczną racjonalnością. Myśl historyczna Pawta Jasienicy i jej recepcja $w$ dobie Polski Ludowej, Kwart. Hist. 120 (2013), nr 1, s. 55-96; A. Kierys, Polska Jasienicy. Biografia publicysty, Kraków 2015. Ten ostatni wydał także niedawno cenny wybór tekstów Historia to nie dziwka. Antologia tekstów Pawła Jasienicy, jego interlokutorów i recenzentów, Kraków 2018. W 2019 r. ukazał się poświęcony w całości twórczości P. Jasienicy numer pisma Sensus Historiae (2019), nr 4. 
sjach. W pierwszych latach powojennych oddziaływanie marksizmu miało w dużym stopniu twórczy i odświeżający charakter. Lata następne to dominacja klasycznego marksizmu stalinowskiego. Wreszcie po 1956 r. można mówić o jego dwóch konkurencyjnych artykulacjach. Doświadczenie „małżeństwa z marksizmem” było dla kilku pokoleń polskich historyków doświadczeniem formacyjnym i ważnym. Dla jednych było to „małżeństwo z miłości”, dla drugich „małżeństwo z rozsądku”, dla innych jeszcze „małżeństwo wymuszone i zaaranżowane”, które przy najbliższej sposobności zakończyło się rozwodem. Po części działo się tak dlatego, że o tym, kto może, a kto nie, nazywać się „marksistą” decydowała władza. W tym kontekście warto zacytować znaną opinię Henryka Wereszyckiego, że nie może być marksistą w kraju, w którym za czołową marksistkę uznawana jest Żanna Kormanowa ${ }^{32}$.

Postępująca liberalizacja życia naukowego w Polsce prowadziła do sytuacji, w której ideologiczne treści doktryny ulegały procesowi erozji, a jednocześnie znaczna część środowiska historycznego, z różnych powodów, skłonna była zaakceptować zarówno wiele jej składników, jak i historiozoficzne przesłanie marksizmu. Swego czasu zwrócił na to uwagę Norman Davies ${ }^{33}$. Mimo wielu zabiegów władz, a chyba także na przekór im, marksizm recypowany był przez polskich historyków wyjątkowo selektywnie. W recepcji tej mieszały się ze sobą wątki teoretyczno-metodologiczne i ideologiczne, zdroworozsądkowe deklaracje i świadome wybory procedury badawczej. To w marksizmie, jak w lustrze, musiały się przeglądać pozostałe opcje metodologiczne, a ich zwolennicy byli zmuszeni podkreślać zbieżne z nim postulaty, zawierając niekiedy niewygodne kompromisy.

We współczesnej rodzimej historiografii w przeciwieństwie do Zachodu marksizm jest obecny jedynie w niewielkim stopniu. Odrzucona została jego warstwa historiozoficzna, charakterystyczne dla niego procedury interpretacyjne i caly aparat pojęciowy. Niekiedy tylko przywołują go piszący na tematy historyczne socjologowie i kulturoznawcy. Tytułem przykładu można wymienić Jana Sowę i jego Fantomowe ciato króla ${ }^{34}$ czy Andrzeja Ledera i Prześniona rewolucję ${ }^{35}$. W obu tych przypadkach marksizm występuje w roli jednej z wielu teorii emancypacyjnych, mających np. uzasadniać postkolonialne z ducha ujęcia przeszłości. Generalnie jed-

32 Szerzej na ten temat zob. Niezwykła epistolografia. Stefan Kieniewicz-Henryk Wereszycki. Korespondencja z lat 1947-1990, wstęp i oprac. E. Orman, Kraków 2013.

33 N. Davies, Boże Igrzysko. Historia Polski, tłum. E. Tabakowska, Kraków 1990 (wyd. 1), t. 1 , s. 42 .

34 J. Sowa, Fantomowe ciało króla: peryferyjne zmagania z nowoczesną formą, Kraków 2011.

35 A. Leder, Prześniona rewolucja: ćwiczenie z logiki historycznej, Warszawa 2014. 
nak w środowisku historyków publiczne przyznawanie się do materialistycznego pojmowania dziejów, cytowanie klasyków marksizmu uchodzi za rzecz wstydliwą ${ }^{36}$. Czy to dobrze, czy źle - to jednak temat na zupełnie inną opowieść.

Nadesłany: 5 IX 2020

Nadesłany po poprawkach recenzyjnych: 13 VIII 2021

Zaakceptowany: 13 VIII 2021

Prof. dr hab. Rafał Stobiecki

Instytut Historii, Uniwersytet Łódzki

ul. A. Kamińskiego 27a

90-219 Łódź

e-mail: rafalsto@uni.lodz.pl

\section{Résumé}

\section{Marxism versus Other Strands in Polish Post-War Historiography}

This paper aims to present the methodological face of Polish historiography after World War II. The author focuses on Marxism and its role in the research practice of historians. Attention was paid to its double status: as a theory of history and as an ideology legitimising the post-war socio-political order. For the transformations in Polish historiography after 1945, the caesura of 1956 was of key importance. It was then that both the uniform, Stalinist version of Marxism disintegrated, and partial pluralism in the ways of understanding history was revived. Some other methodological trends, polemicising with the Marxist proposal and present in Polish historiography after 1956 are also briefly mentioned (the Annales school, individualistic historicism).

Translated by Agnieszka Tokarczuk

\section{Bibliografia/Bibliography}

Bajer M., Blizny po ukąszeniu, Warszawa 2005

Barycz H., O nowe drogi polskiej historiografii, Nauka i Sztuka 2 (1946), s. 324-336 Baszkiewicz J., Wolność, Równość, Własność. Rewolucje burżuazyjne, Warszawa 1981

36 W ostatnim czasie sytuacja jednak zaczyna się zmieniać. Jako przykład pracy, w której inspiracja marksistowska jest wyraźnie widoczna, można podać syntezę Adama Leszczyńskiego, Ludowa historia Polski. Historia wyzysku i oporu. Mitologia panowania, Warszawa 2020. 
Bloch M., Pochwała historii, czyli o zawodzie historyka, przeł. W. Jedlicka, Warszawa 1960

Buszko J., Historia Polski 1864-1948, Warszawa 1979

Connelly J., Zniewolony uniwersytet: sowietyzacja szkolnictwa wyższego w Niemczech Wschodnich, Czechach i Polsce, przeł. W. Rodkiewicz, Warszawa 2014

Czapliński W., Zarys dziejów Polski do roku 1864, Kraków 1985

Czyżewski A., Proces destalinizacji polskiej nauki historycznej w drugiej połowie lat 50. XX wieku, Warszawa 2007

Davies N., Boże Igrzysko. Historia Polski, t. 1, tłum. E. Tabakowska, Kraków 1990

Duby G., Geremek B., Passions communes: entretiens avec Philippe Sainteny, Paris 1992

Duby G., Geremek B., Wspólne pasje, przeł. z jęz. franc. E.T. Sadowska, Warszawa 1995

Dzieje Polski, red. J. Topolski, Warszawa 1976

Gałkowski P., Poznawanie dziejów czy wytwarzanie historii? Jerzego Topolskiego przemiany poglądów na uprawianie historii, Poznań 2019

Gierowski J.A., Historia Polski 1505-1764, Warszawa 1978

Gierowski J.A., Historia Polski 1764-1864, Warszawa 1979

Goldmann L., Nauki humanistyczne a filozofia, przeł. E. Jerzewska, Warszawa 1961

Górny M., Przede wszystkim ma być naród... Marksistowskie historiografie w Europie Środkowo-Wschodniej, Warszawa 2007

Grabski A.F., Stalinowski model historiografii, Dzieje Najnowsze 24 (1992), nr 3, s. $23-45$

Grodecki R., Lepszy K., Stowo od Redakcji, Kwartalnik Historyczny 53 (1946), nr 1 Historia to nie dziwka. Antologia tekstów Pawta Jasienicy, jego interlokutorów i recenzentów, red. A. Kierys, Kraków 2018

Iggers G., Historiography in the Twentieth Century. From Scientific Objectivity to the Postmodern Challenge, Hanover-London 1997

Kapica P., Pisma o naukie, Moskwa 1989

Kieniewicz S., Pamiętniki, Kraków 2021

Kierys A., Polska Jasienicy. Biografia publicysty, Kraków 2015

Kijowski A., Dziesięć lat życia, [w: ] Rachunek pamięci, wstęp M. Głowiński, Warszawa 2012, s. 133-159

Kołakowski L., Pochwała niekonsekwencji. Pisma rozproszone z lat 1955-1968, oprac. Z. Mentzel, t. I-III, Londyn 1989

Kukiel M., Nauki historyczne pod komunistycznym ciśnieniem, Przegląd Polski 2 (1949) 
Kula M., Mimo wszystko bliżej Paryża niż Moskwy. Książka o Francji, PRL i o nas, historykach, Warszawa 2010

Kula W., Rozważania o historii, Warszawa 1958

Kula W., Teoria ekonomiczna ustroju feudalnego. Próba modelu, Warszawa 1962

Kwiatkowski S., Polska mediewistyka w czasach maszynopisu. O wymuszonej modernizacji i okolicznościach jej przemijania, Poznań 2010

Labuda G., Rozwój metod dziejopisarskich od starożytności do wspótczesności. Część I: do schytku XIX wieku, Poznań 2003

Leder A., Prześniona rewolucja: ćwiczenie z logiki historycznej, Warszawa 2014

Leszczyński A., Ludowa historia Polski. Historia wyzysku i oporu. Mitologia panowania, Warszawa 2020

Malewski A., Topolski J., Metoda materializmu historycznego w pracach historyków polskich, Studia Filozoficzne 6 (1959), s. 129-154

Małowist M., Wschód a Zachód Europy w XIII-XVI wieku. Konfrontacja struktur spoteczno-gospodarczych, Warszawa 1973

Markiewicz W., Miejsce i rola marksizmu $w$ badaniach społecznych, Nauka Polska 1 (1984), s. 43-54

Marksizm i istoriczeskaja nauka w stranach centralnoj i jugowostocznoj Jewropy (18701965), red. W.A. Djakow, Moskwa 1993

Mękarski A., Między mitem a polityczna racjonalnością. Myśl historyczna Pawta Jasienicy i jej recepcja $w$ dobie Polski Ludowej, Kwartalnik Historyczny 120 (2013), nr 1, s. 55-97

Miercałow A., Istorija i stalinizm, Moskwa 1991

Mikołajczyk M., Rewizjoniści. Obecność w dyskursach okresu PRL, Kraków 2014

Niezwykła epistolografia. Stefan Kieniewicz - Henryk Wereszycki. Korespondencja z lat 1947-1990, wstęp i oprac. E. Orman, Kraków 2013

Pleskot P., Intelektualni sąsiedzi. Kontakty historyków polskich ze środowiskiem „Annales" 1945-1989, Warszawa 2010

Pomian K., Wśród mistrzów i przyjaciót, Gdańsk 2018

Pomorski J., Homo metahistoricus. Studium sześciu kultur poznających historię, Lublin 2019

Radomski A., Kultura - tekst - historiografia, Lublin 1999

Rutkowski T.P., Nauki historyczne w Polsce 1944-1970. Zagadnienia polityczne i organizacyjne, Warszawa 2007

Siewierski T., Marian Małowist i krag jego uczniów. Z dziejów historiografii gospodarczej $w$ Polsce, Warszawa 2016 
Sitek R., Warszawska szkoła historyków idei. Między historią a teraźniejszością, Warszawa 2000

Sosnowska A., Zrozumieć zacofanie. Spory historyków o Europę Wschodnia (1947-1994), Warszawa 2004

Sowa J., Fantomowe ciało króla: peryferyjne zmagania z nowoczesna forma, Kraków 2011

Stobiecki R., Historia pod nadzorem. Spory o nowy model historii $w$ Polsce (II połowa lat czterdziestych - początek lat pięćdziesiątych), Łódź 1993

Stobiecki R., Historiografia PRL. Zamiast podręcznika, Łódź 2020

Stobiecki R., Jerzy Topolski (1928-1998). Marksista, który miat odwagę różnić się od innych, [w: tegoż, Historycy polscy wobec wyzwań XX wieku, Poznań 2014, s. 351-373

Stobiecki R., Między dogmatem ideologicznym a modernizacja. Marksizm a historiografia w Polsce po drugiej wojnie światowej, [w:] tegoż, Historiografia PRL. Ani dobra, ani mądra, ani piękna... ale skomplikowana, Warszawa 2007, s. 163-183

Stobiecki R., Najnowsze dzieje Polski w syntezach historycznych okresu PRL, Przegląd Zachodni 4 (1994), s. 111-122

Topolski J., Polish Historiography and Marxism After World War II, [w: ] Asian and European History in Transitional Period. Collection of Essays in the Celebration of Dr. Tae-Young Lee's Sixtieth Birthday, Seoul 1992, s. 403-414

Topolski J., Polish Historiography and Marxism After World War II, Studies in Soviet Thought 43 (1991), No. 2: Polish Philosophy at the Crossroads, s. 169-183

Zarys historii Polski, red. J. Tazbir, Warszawa 1979

Wyrozumski J., Historia Polski do roku 1505, Warszawa 1978

Zybertowicz A., Między dogmatem a programem badawczym. Problemy stosowania materializmu historycznego we wspótczesnej historiografii polskiej, Warszawa 1990 Żarnowski J., Historia społeczna. Metodologia - ewolucja - perspektywy, Warszawa 2011 